\title{
Study of the Changing Farmland to Forest Question with the Game Theory Thought
}

\author{
XUE Shejiao \\ College of Mathematics and Information Science, Weinan normal university, Weinan, China
}

Keywords: changing farmland into forest, compensate, game theory.

\begin{abstract}
In this year, many outputs were acquired by project of changing farmland into forestry. But there exist some things which restrict the sustainable development of project. The main reason is compensatory problem. This paper uses completely dynamic game theory to set up dynamic mode and from compensatory point of view to analyze sustainable development of project of changing farmland into forestry. Some suggestions on sustainable development of changing farmland into forest are given:(1) develop different compensation standard according to economic-forest and eco-forest; (2) apply different compensation standard according to different areas;(3) extend compensatory period and pay different amount of compensation on stage;(4) adjust industry structure in project areas, and more skill trainings should be held to farmer.
\end{abstract}

\section{Introduction}

Returning farmland to forest project is at present the country has been launched seven ecological engineering of the largest and most investment a ecological engineering. Pilot the project began in 1999, in 2000 launched a comprehensive, covering 25 provinces and xinjiang production and construction corps, the great achievements of returning farmland to forest project, to promote the ecological environment improvement. But as we will continue to implement on returning farmland to forest, some problems appeared in the process of returning farmland to forest, such as subsidies period provided for returning farmland to forest in China, "countries every year according to returning farmland area grasslands shall be required to subsidize, economic forest benefits for 5 years, ecological forest subsidy for 8 years", after the expiration of returning farmland to forest subsidy. Once money subsidies have no, some of the returning farmland to forest farmers livelihood will be affected, farmland and destroying forest farmers and results of returning farmland to forest will be destroyed.

Analysis from the perspective of economics, returning farmland to forest project is country specific period of time by buying farmers of arable land to produce the process of ecological products, as the country to a certain amount of money to pay to buy from farmers land use rights. On the supply side, farmers for the land use right transfer must be voluntary, and voluntary is built on national compensation provided to farmers at least maintain the existing standard of living. On the demand side, the country each year should determine the purchase quantity according to the resources and ecological environment situation and the ability to pay the money. Is a dynamic game between the government and farmers, and reasonable monetary pay to buy the land use right is the key to guarantee to sustainable implementation of returning farmland to forest project. Based on the dynamic model of game theory construction of returning farmland to forest, from the perspective of compensation to analyze sustainability of the project of returning farmland to forest.

Game Theory, game Theory is also known as game Theory (Games going), is the study is in the nature of struggle or competition phenomenon, the Theory and method of it is both a new branch of modern mathematics, is an important subject of operational research. Generally speaking, the game theory is a kind of "game theory". Its accuracy is defined as: game theory is about the strategy of interaction theory, that is to say, it is the theory of rational behavior in social situation, in which each player's choice of their own behavior to his sense of how other players will reflect basic ${ }^{[1]}$. In short, the game theory research in the form of a "battle of wits" between people and consequences. When people interests conflict, everyone benefits depends not only on their actions, also depend on 
others to take action, so everyone needs to each other's behavior choice made response to own the most powerful.

\section{The generalization of the meaning of returning farmland to forest has the following four}

(1) Returning farmland to forest is to improve the ecological environment to promote social and economic sustainable development of urgent need.

(2) Returning farmland to forest is the adjustment of rural industrial structure, increase farmers' income and realize the farmers out of poverty to become rich, an effective way to promote local economic development.

(3) Returning farmland to forest is stimulating domestic demand, maintain the rapid growth of national economy at present stage major strategic measures.

(4) Returning farmland to forest project is China's earth is undergoing a change in the way of land use, is to promote China's civilization degree.

This is a remarkable major projects, also known as "days font project". Can say returning farmland to forest project is no longer a simple ecological environment construction, but with the environmental management, rural development and economic growth is directly related to the complex social system engineering, is a "good work" and "popular project". Is the general secretary jiang zemin "the three represents" important thought and practice of agriculture rural work, the embodiment of comprehensive construction well-off society. At present, the policy of returning farmland to forest has embraced by grassroots cadres and the masses, has been widely recognized the social from all walks of life. ", as it were, to speed up the pace of returning farmland to forest, is the adjustment of agricultural structure, to strengthen the ecological construction of major initiatives, is also the current increase farmers' income, the most direct, the most efficient way to but also the fundamental way of impoverished mountainous area of poverty to get rich."

\section{In the project of returning farmland to forest farmers and dynamic game model of the government}

Model elements. 1) model elements

(1).The players: farmers and the government, they are the game of returning farmland to forest project decision-making and policy makers.

(2).Policy set: the policy set refers to a collection of strategies may be taken by the government and farmers. Each player when making decisions can be in accordance with the rational choice of different strategies or the combination of a variety of strategies, each policy set should have at least two different strategies.

(3). The order of the game: for a dynamic game, the game order to influence the outcome of the final game equilibrium, namely although theoretical game starts with the farmers. However, according to the specific situation of returning farmland to forest project in our country, there is no active farmers returning farmland and demand compensation, even if the farmers take the initiative to change the slope to economic forest and timber forest, but also because of considering their income increase. And in China's current policy system and financial conditions, planning on returning farmland to forest and there is no actual farmland or not returning farmland to forest planning of forest land is no compensation, so in this paper, the dynamic game analysis only game begins in the situation of the government.

(4) Payoff function: when all the players strategy determine later, they will get the corresponding "benefits". The payoff function indicated the effectiveness of players from the game level, it is a function of all players. This research adopts the net income of farmers and government to represent its utility in returning farmland to forest project.

2) The model assumptions

(1)Game the body of the farmers and the government is rational, both in their own net profit maximization as the goal. 
(2) To assume an extension, the government does not exist multi-objective decision-making, the implementation of returning farmland to forest policy based on government on the basis of minimum compensation expenses to maximize the ecological value, without regard to increase farmers' income, the conversion of land use structure, adjusting agricultural production mode, and other multiple goals.

(3). Hypothesis is free decision individual farmers and assume that the government compensation is not enough to compensate for the opportunity cost of farmers, farmers is on the basis of their own benefit maximization choose not returning farmland or planting.

(4). Assuming that farmers economic forest in the compensation period can gain economic benefits; No economic benefits, ecological forest in the compensation period at the end of the phase compensation ecological forest can get quite a few of economic benefits.

(5). Assume that the government and farmers and benefits each other understand each other's strategic space function, has the complete information to the other party, and before the next action, all previous actions can be observed, namely, this model is a complete and perfect information dynamic game [2].

\section{Model is built and explanation}

Returning farmland to forest project in the cost of the government and farmers income is embodied in the following aspects:

Government revenue:

A1 for ecological benefit of ecological forest per monetary value;

A2 is economic forest ecological benefit of monetary value per acre; Obviously: A1 > A2

Farmers income structure: I0 said before returning farmland per acre of arable land to create net income;

$\mathrm{X}$ is the conversion of farmers before other income;

I1 is expected net income after returning farmland per mu ecological forest;

I2 is economic forest expected net income per acre after returning farmland;

$\mathrm{Y}$ is farmers after grain for other income (including proprietary business, migrant workers and breeding, etc.);

$\mathrm{C} / \mathrm{c}$ is a country with a per mu woodland gain compensation funds

The government cost: $\mathrm{C}$ is full specified amount per acre compensation funds; $\mathrm{c}$ is not full specified amount per acre compensation; Full compensation refers to make up for farmland and the loss of the opportunity cost of original land. In view of the policy of economic forest and ecological compensation term is 5 and 8 years respectively, this study points and compensation within the term of compensation period after the end of game analysis in two stages:

\section{The period of compensation.}

Table 1. The government and farmers game within the term of compensation

\begin{tabular}{|l|l|l|l|}
\hline \multicolumn{2}{|c|}{} & \multicolumn{2}{l|}{ government } \\
\cline { 3 - 4 } \multicolumn{2}{|c|}{} & compensation & No compensation \\
\hline farmers & Ecological forest & $\left(\mathrm{A}_{1}-\mathrm{C}, \mathrm{I}_{1}+\mathrm{Y}\right)$ & $\left(0, \mathrm{I}_{0}+\mathrm{X}\right)$ \\
\cline { 2 - 4 } & Economic forest & $\left(\mathrm{A}_{2}-\mathrm{C}, \mathrm{I}_{2}+\mathrm{Y}\right)$ & $\left(0, \mathrm{I}_{0}+\mathrm{X}\right)$ \\
\hline
\end{tabular}

Using backward induction compensation term of the government and farmers sub-game refining Nash equilibrium solution is[3]:

(1) In the period of subsidies, economic forest and ecological benefits. To stimulate farmers returning farmland to forest rational government will choose to aid. 
(2) In the case of government compensation. Because the I2 + Y > I1 + Y, rational farmers will choose better economic forest economic benefit. So the Nash equilibrium solution for government compensation and farmers also economic forests: (A2 - C, I2 + Y)

Suppose $\mathrm{I} 0+\mathrm{X}>\mathrm{I} 2+\mathrm{Y}$, cannot make up for the sum of all income after returning farmland before returning the sum of income, the equilibrium is $(0, \mathrm{I} 0+\mathrm{X})$, even if the government made it clear that will compensate, farmers will choose not to farmland.

After the phase compensation. (1) After the end of ecological compensation the period

Table 2. After the end of ecological compensation period. The government and farmers game

\begin{tabular}{|l|l|l|l|}
\hline \multirow{2}{*}{ The game party } & Continue to subsidies & Removal of subsidies \\
\hline \multirow{2}{*}{ Government } & \multirow{2}{*}{$\mathrm{A}_{1}-\mathrm{C} / \mathrm{c}$} & Farming again & 0 \\
\cline { 3 - 4 } & & Continue to farmland & $\mathrm{A}_{1}$ \\
\hline \multirow{2}{*}{ Farmer } & $\mathrm{Y}+\mathrm{I}_{1}+\mathrm{C} / \mathrm{c}$ & Farming again & $\mathrm{X}+\mathrm{I}_{0}$ \\
\cline { 3 - 4 } & & Continue to farmland & $\mathrm{Y}+\mathrm{I}_{1}$ \\
\hline
\end{tabular}

When $\mathrm{I} 0>\mathrm{X}+\mathrm{Y}+\mathrm{I} 1$, if countries cancel subsidies, rational farmers will choose planting, the government know the choice of farmers after the cancellation of subsidies, and $\mathrm{A} 1-\mathrm{C} / \mathrm{C}>0$, so the rational government will choose to continue, for ecological benefit of $\mathrm{A} 1$. The equilibrium solution of $(\mathrm{A} 1-\mathrm{C} / \mathrm{C}, \mathrm{Y}+\mathrm{I} 1+\mathrm{C} / \mathrm{C})$, namely countries continue to choose subsidies, farmers keep returning farmland.

When $\mathrm{Y}+\mathrm{I} 1>\mathrm{X}+\mathrm{I} 0$, there are two equilibrium solution $(\mathrm{A} 1-\mathrm{C} / \mathrm{C}, \mathrm{Y}+\mathrm{I} 1+\mathrm{C} / \mathrm{C}),(\mathrm{A} 1, \mathrm{Y}+\mathrm{I} 1)$, the government also choose subsidies or not subsidies, farmers will keep returning farmland, the government ecological benefit is A1, starting from the government fiscal expenditure minimization, the optimal solution for (A1, Y + I1), no allowance.

If after the compensation period introduced, $\mathrm{r}(0<\mathrm{r}<1)$ the probability of compensation after continue to compensate for the government; $\mathrm{W}(0<\mathrm{W}<1)$ as the probability of farmers planting after the compensation; $\mathrm{N}$ to compensate for fixed number of year (in the fixed value); $\mathrm{M}$ for the government and the farmers are acceptable efficiency is poor.

So. Can be obtained. The expectations of the government expect function

$$
\begin{aligned}
& \mathrm{E}[\mathrm{r}]=\sum_{i=1}^{n}\left[\left(A_{1}-C / c\right) r i+0(1-r) w i+A_{1}(1-r)(1-w) i\right] \\
& =\sum_{i=1}^{n}\left[\left(A_{1}-C / c\right) r i+A_{1}(1-r)(1-w) i\right]
\end{aligned}
$$

Function for farmers incomes and expect function

$\mathrm{E}[\mathrm{w}]=\sum_{i=1}^{n}\left[\left(Y+I_{1}+C / c\right) r i+(1-r)\left(X+I_{0}\right) w i+(1-r)\left(Y+I_{1}\right)(1-w) i\right]$

After the compensation period when $[\mathrm{r}]-[\mathrm{w}] \mathrm{E}|\mathrm{E}| \mathrm{M}$ or less, this can be a equilibrium solution: governments choose to compensation, ecological forest farmers choose to continue

(2) After the economic forest compensation period 
Table 3. The economic forest compensation period after the end of the government and farmers

\begin{tabular}{|l|l|l|l|}
\hline \multirow{2}{*}{ The game party } & Continue to subsidies & \multicolumn{2}{|l|}{ Removal of subsidies } \\
\hline \multirow{2}{*}{ Government } & \multirow{2}{*}{$\mathrm{A}_{2}-\mathrm{C} / \mathrm{c}$} & Farming again & 0 \\
\cline { 3 - 4 } & & Continue to farmland & $\mathrm{A}_{2}$ \\
\hline \multirow{2}{*}{ Farmer } & $\mathrm{Y}+\mathrm{I}_{2}+\mathrm{C} / \mathrm{c}$ & Farming again & $\mathrm{X}+\mathrm{I}_{0}$ \\
\cline { 3 - 4 } & & Continue to farmland & $\mathrm{Y}+\mathrm{I}_{2}$ \\
\hline
\end{tabular}

Analysis as above, but there is a difference in ecological size A1, A2, but does not affect the A2 $->0 \mathrm{C} / \mathrm{c}$, so does not affect the government's decision-making, therefore obtains equilibrium as follows:

When $\mathrm{I} 0>\mathrm{X}+\mathrm{Y}+\mathrm{I} 2$, equilibrium solution for $(\mathrm{A} 2-\mathrm{C} / \mathrm{C}, \mathrm{Y}+\mathrm{I} 2+\mathrm{C} / \mathrm{C})$, namely countries continue to choose subsidies, farmers keep returning farmland; When $\mathrm{I} 0<\mathrm{X}+\mathrm{Y}+\mathrm{I} 2$, there are two equilibrium solution (A2, Y + I2) and (A2 - C/C, Y + I2 + C/C),

When the government subsidies or not you choose subsidies, farmers will keep returning farmland, the government ecological benefit both from the government fiscal expenditure for A2 minimize, the optimal solution for (A2, Y + I2), no allowance.

After the compensation period as well as ecological forest, we also introduce the variable $\mathrm{k}(0<$ $\mathrm{k}<1)$ the probability of compensation after continue to compensate for the government; $\mathrm{E}(0<\mathrm{e}<$ 1) for the probability of farmers planting after the compensation; $N$ to compensate for fixed number of year (in the fixed value); $Q$ for the government and the farmers are acceptable efficiency is poor.

The government income expectation function can be obtained

$\mathrm{E}[\mathrm{k}]=\sum_{i=1}^{n}\left[\left(A_{2}-C / c\right) k i+0(1-r) e i+A_{2}(1-k)(1-e) i\right]$

$=\sum_{i=1}^{n}\left[\left(A_{2}-C / c\right) k i+A_{2}(1-k)(1-e) i\right]$

Function for farmers incomes and expect

$\mathrm{E}[\mathrm{e}]=\sum_{i=1}^{n}\left[\left(Y+I_{2}+C / c\right) k i+(1-k)\left(X+I_{0}\right) e i+(1-k)\left(Y+I_{2}\right)(1-e) i\right]$

After the compensation period when $\mathrm{E}[\mathrm{k}]-\mathrm{E}[\mathrm{e}] \mid<=\mathrm{Q}$, this can be a equilibrium solution: governments choose to compensation, economic forest farmers to choose. From the end of the phase compensation of dynamic game model, you can see that if the government doesn't increase economic support for farmers. If the economic benefits of the cultivated land is less than the economic benefits of its agricultural fields, the farmers would have been easy to appear first planting phenomenon.

\section{Analysis and policy recommendations}

It can be seen through the analysis of the dynamic game model is restricting our project of returning farmland to forest sustainability is the key problem of compensation, the compensation standard and compensation term problem. By implementing difference extend the project of returning farmland to forest compensation for compensation, and implement annual for farmers in different amount of compensation is ensure the sustainability of the project such as of the effective measures.

Implements different compensation for ecological forest and economic forest. At present some areas not in strict accordance with the provisions in proportion to ecological and economic forest, through to the difference of ecological and economic forest compensation, can effectively solve the problem. 
The current policy of ecological and economic forest growers to give the same standard of compensation, this for two different sorts of forest for farmers is not fair. To the plant production cycle is long, big risk, even in the young period of ecological forest planting farmers no benefits, is unfair. So in the first game when the choice, the rational economic man will tend to choose quick effect, short production cycle, benefit risk relatively small economic forest crops. Due to the state of ecological and economic forest compensation standard, at the same time, ecological forest can't earn money in the compensation issue, inevitable: ecological forest yields less than the situation of economic benefits, namely per mu ecological compensation fund should be greater than, or at least equal to that of the expected net income after returning farmland per mu economic forest and economic forest the sum of compensation funds, only in this way will encourage farmers also ecological forest. So the state should set different compensation standard, at the same time, should improve the ecological compensation standard.

Difference compensation standards for different area. At present, the returning farmland to forest compensation policy is one size fits all. According to the state council on further perfecting several opinions of returning farmland to forest policy measures, the country free of charge to provide food and cash allowances for farmland: the Yangtze river basin and the south, woodland annual subsidy (raw grain) $150 \mathrm{~kg}$ of grain per mu and northern regions, woodland annual subsidies (raw grain) $100 \mathrm{~kg}$ of grain per mu. Cash is 20 yuan per mu woodland subsidies every year. Food subsidies and cash fixed number of year, grassland allowance calculated at 2 years; Also economic forest benefits calculated at 5 years; And ecological benefits of short duration calculated at 8 years. Visible only in accordance with the current policy of the Yellow River and the Yangtze river basin to determine compensation standards, without taking into account different parts of the social economic development level. Some parts of the farmers income is good, too little and lead to $\mathrm{X}+$ $\mathrm{I} 0>\mathrm{I}_{2}+\mathrm{Y}$, most farmers are not willing to "refund", even planting, seriously affected the country to the overall effect of the ecological recovery. Some farmers cultivated land income is low, the compensation amount and more, after returning farmland income is greater than the income before returning farmland, farmers will not actively looking for other income sources. Although at present the height of a unified compensation standard transparent, and easy to operate, is conducive to protect the interests of the farmers and avoid the occurrence of local governance issues. But as a result of China's regional differences between social economy and natural environment, highly unified compensation standard in the specific implementation process exists the effect of the policy of serious imbalance, the efficiency of the state compensation funds being questioned.

Proposal should be based on returning farmland to forest area natural condition and social economic development level to determine the difference between compensation standard, make economic compensation as possible consistent with the actual output, woodland, this is to ensure that the project of returning farmland to forest and grass to continue in-depth, and obtain higher national finance service efficiency of funds. Of course, compared with the current compensation standard implementation plan, proposal of operating cost, regulation cost is relatively high. But from the point of game model analysis, returning farmland to forest project of great ecological benefit is far higher than the cost of investment, so the feasibility of the scheme are operating.

Extend the project of returning farmland to forest compensation for 5.3, and implement annual for farmers in different amount of compensation. Through the game model, you can see that at the end of the phase compensation, if the income of farmers' income is less than before returning farmland to forest, will choose planting. Therefore, in the limited state financial resources, suggested that the government should apply compensation term incentives, in the implementation of difference compensation cases, the term of compensation may be extended, annual to different amounts of compensation measures such as farmers, to follow the law of diminishing, the next year of appropriate lower than the previous year $10 \sim 30$ yuan per mu of compensation, at the same time, the farmers compensation for longer periods, in a bigger afforestation period to more money compensation, there is a certain income less namely forest period or not, but at least should be protect generation economic income is relatively stable, give the consciousness to crisis already so, can accelerate the self development and self compensation. 
In the project area industrial structure adjustment, strengthen the farmer skill training, raise the level of farmers income. Can be seen from the game model, the government must be at the beginning of the returning farmland to do a good job of supporting sustainable industries, and fully develop the farmer's self compensation and the ability of self-development, enable farmers realized the benefits of returning farmland to forest. So at the end of the phase compensation, farmers income levels are not end compensation to reduce, won't appear the phenomenon of planting. The government can through skills training of the farmers, protect the farmland farmers private property rights as well as through policy adjustment, such as preferential policies, to establish farmers obtain the stability of returning farmland to forest direct income expectations. At the same time should adhere to the "who afforestation, who management, who benefits" principle, the implementation of the "returning farmland to forest (grass), afforestation, with grain DaiZhen, individual contracting" measures, the returning farmland to forest and poverty alleviation and development, the comprehensive agricultural development, ecological construction and socialist new rural construction and other projects, the combination of external benefit parts of the project of returning farmland to forest internal to the economic interests of the local farmers. Hydro-geologic conditions and through policy guidance makes the farmers onto the road of self accumulation and self development, participate in the development of less impact on the ecological resources.

\section{Acknowledgment}

By field characteristic discipline construction project (14 tsxk02) funding.

(math) support discipline construction projects funded by shaanxi province.

Soluble tumor virus tumor treatment process analysis of the dynamic model (10 yks004)

Mathematics curriculum diversity to explore and the diversity of students skills (JG201348), 5. Dual-use materials key laboratory open project (15 jmr18) [author's brief introduction] Xue Shejiao (1965 -), race, han, weinan in shaanxi province, associate professor, bachelor, mainly engaged in the study of economic mathematics and basic mathematics. E-mail:xueshejiao@126.com

\section{References}

[1] Huang Tao. Tutorial game theory - the theory and application. The capital university of economics and trade publishing house, 2004. 1-2.

[2] Li Guangjiu. Game theory based tutorial [M]. Chemical industry press, 2004. 40-41.

[3]Zhang WeiYing .Game theory and information economics[M]. Shanghai people's publishing house, Shanghai sanlian bookstore. 34

[4] Stevenc.Hackett.2001. Environmental and Natural Resource Economics.M.E. Sharpe.

[5] http://baike.baidu.com/view/51168.htm.

[6] shaw. Game theory and its application [M]. Shanghai sanlian bookstore.

[7] Cliveel.Spash.1999.The Development of Environmental Thinking in Economics.The White Horse pees.39-41.

[8] Hardin. 1986. Tragedy of the Commons. Science 162.1243-1248. 